\title{
РОЛЬ ТА МІСЦЕ ДЕРЖАВНОГО НАГЛЯДУ В ІНСТИТУЦІОНАЛЬНОМУ МЕХАНІЗМІ ЗДІЙСНЕННЯ ФІНАНСОВОÏ ПОЛІТИКИ УКРАЇНИ
}

\author{
ROLE AND PLACE OF STATE SUPERVISION \\ IN THE INSTITUTIONAL MECHANISM \\ OF IMPLEMENTATION OF FINANCIAL POLICY OF UKRAINE
}

\author{
Кміть Віра Мирославівна \\ кандидат економічних наук, доцент, \\ Львівський національний університет імені Івана Франка \\ ORCID: https://orcid.org/0000-0001-6845-8139 \\ Білаш Юлія Володимирівна \\ здобувач вищої освіти 2 курсу ОС «Магістр», \\ Львівський національний університет імені Івана Франка \\ ORCID: https://orcid.org/0000-0002-7815-7644 \\ Kmit Vira, Bilash Yuliia \\ Ivan Franko National University of Lviv3
}

\begin{abstract}
У статті визначено сутність, роль та місце нагляду у процесі здійснення фрінансової політики України. Обґрунтовано необхідність проведення державного нагляду, виявлено його недоліки в процесі інституціоналізації та перспективи розвитку. Досліджено організаційні й правові засади контролю та запропоновано напрями їх вдосконалення. На основі проведеного дослідження доведено необхідність підвищення есрективності державного нагляду як складової інституціонального механізму здійснення фрінансової політики. Це сприятиме становленню і зміцненню економічного становища країни в цілому та розвитку підприємництва зокрема. Вивчаючи місце нагляду в реалізації фрінансової політики, акцентовано увагу на низькій ефективності контрольних функцій фрінансових інститутів та наголошено на доцільності їх реформування та гармонізації.

Ключові слова: нагляд, контроль, фрінансова політика, фрінансовий контроль, інституціональний механізм, фрінансові інститути, фрінансові ресурси.

В статье определена сущность, роль и место надзора в процессе осуществления фринансовой политики Украины. Было обоснована необходимость проведения государственного надзора, выявлены его недостатки в процессе институционализации. Исследовано организационные и правовые основы контроля и предложены направления их совершенствования. На основе проведенных исследований обоснована необходимость повышения эфрфективности государственного надзора как составляющей институционального механизма осуществления фринансовой политики. Это будет способствовать становлению и укреплению экономического положения страны в целом и развития предпринимательства в частности. Определяя место надзора в реализации фринансовой политики было доказано, что контроль является составной подсистемой фринансового института.

Ключевые слова: надзор, контроль, фринансовая политика, фринансовый контроль, институциональный механизм, фринансовые институты, фринансовые ресурсы.
\end{abstract}

The article defines the essence, role and place of supervision in the process of implementing the financial policy of Ukraine. The necessity of state supervision was substantiated, its shortcomings in the process of institutionalization were revealed. The organizational and legal bases of control are investigated and the directions of their improvement are offered. On the basis of the conducted researches the necessity of carrying out the state control in the basis of the institutional mechanism which will promote formation and strengthening of an economic position of the country and development of business by observance of supervisory procedures is proved. Determining the place of supervision in the implementation of financial policy, it was proved that control is an integral subsystem of the financial institution. The growth of financial violations in Ukraine is caused not by the lack of institutional structure of state financial control, but by the weakness of its theoretical, methodical and methodological framework, shortcomings in the organization of the control process. A prerequisite for building an effective system of public financial control 
is the formation of its institutional foundations and improving the mechanism of such control. At the same time, the institutional principles of public financial control are one of the important conditions of its system, they ensure its legitimacy and integrity, the relationship of elements of the control system. Institutionalization of the state financial control allows to regulate the activities of the subjects of control and to determine their competencies and limits of authority. The further welfare of the population and the stability of the economy depend on the effectiveness of state supervision. It is important to ensure and maintain an appropriate level of control and effectiveness of financial policy management through the institutional mechanism. The purpose of the article is to reveal the economic essence of control, its place in the institutional mechanism of financial policy and determine the role in socio-economic development of the country.

Keywords: supervision, control, financial policy, financial control, institutional mechanism, financial institutions, financian resources.

Постановка проблеми. Зростання обсягів фрінансових правопорушень в Україні внаслідок несформованої інституціональної моделі фрінансової політики, прогалин у забезпеченні процесу нагляду та використання застарілих фрорм контролю унеможливлюють здатність держави до ефрективного забезпечення фрінансової політики і призводить до зниження ефективності контрольних фуункцій державних органів.

Оскільки від ефективності нагляду залежить подальший добробут населення та стабільність економіки, важливим $є$ забезпечення і дотримання належного рівня контролю та ефрективність управління фрінансовою політикою через інституціональний механізм.

Аналіз останніх досліджень і публікацій. Значна кількість українських та зарубіжних науковців займалися вивченням питань контролю, серед яких варто виокремити таких як В. Загорський, В. Піхоцький, В. Рудик, В. Синчак, І. Адаменко, Л. Васільєва, Л. Худолій, М. Дем'яненко, Н. Ботвіна, Н. Виговська, Н. Прокопенко, О. Гудзь, О. Моісеєнко, О. Олійник, О. Петрук, О. Прутська, П. Макаренко, П. Стецюк, які вивчали проблеми фрінансового контролю, фрінансової політики, фрінансового механізму. Інституціональні засади фрінансової політики як інструмента впливу на соціальноекономічний розвиток країни досліджували такі вчені, як А. Вагнер, Б. Болдирєв, Дж. Б'юкенен, Дж. Стігліп, Л. Дробозіна, Ш. Бланкарт та інші. Попри вагомий внесок згаданих учених у дослідженні ролі фрінансової політики і, зокрема, державного нагляду та фрінансового контролю, актуальним питанням залишається низька ефрективність останніх та продовження наукових пошуків їх вирішення в контексті удосконалення інституціонального механізму здійснення фрінансової політики в Україні.

Постановка завдання (мета статті). Передумовою фрормування ефрективної системи державного нагляду $\epsilon$ фрормування його інституціональних засад, що зумовлює удосконалення механізму забезпечення фрінан- сової політики. У той же час інституціональні засади контролю $є$ однією із важливих умов його системності, оскільки забезпечують його легітимність і цілісність, взаємозв'язок елементів системи контролю. Інституціоналізація фрінансового контролю дає змогу налагодити діяльність суб'єктів контролю та забезпечити реалізацію ефективної фрінансової політики.

Метою статті $\epsilon$ розкриття економічної сутності державного нагляду, його місця в інституціональному механізмі здійснення фрінансової політики та визначення ролі у соціально-економічному розвитку країни.

Виклад основного матеріалу дослідження. Для забезпечення належного фрункціонування інституціонального механізму забезпечення фрінансової політики необхідним $€$ створення оптимального організаційно-інституціонального середовища. Адже саме воно забезпечує можливість визначення першочергових векторів розвитку фрінансової політики та подальші напрями ії̈ здійснення, вибір найефективніших економічних і соціальних інститутів та їхня гармонізація.

Становлення інституту фрінансової політики відбувалося під впливом еволюційних процесів розвитку українського суспільства. Загалом, інститут фрінансової політики включає процес визначення норм та контроль за дотриманням, норми поведінки, які налагоджують фрінансові механізми та забезпечують належний рівень реалізації фрінансової політики і забезпечують ії стабільний розвиток [1, с. 236].

Формування системи державних органів, які в сукупності утворюють інституціональний механізм здійснення державної фрінансової політики, було обумовлене необхідністю виконання ними відповідних державних фрункцій, які можна звести до таких трьох груп [2, с. 115]:

1) фрормування державної фрінансової політики;

2) реалізація державної фрінансової політики;

3) контроль за виконанням державної фрінансової політики. 
Такий поділ є відносно умовним, оскільки не виключає можливості того, що деякі державні органи можуть бути наділені повноваженнями як щодо виконання фрункції фрормування, так і щодо реалізації чи контролю за виконанням державної фрінансової політики одночасно.

Функція срормування державної фрінансової політики органами інституціонального механізму полягає у діяльності компетентних органів держави щодо встановлення стратегічних цілей, завдань, основних принципів та напрямів державної діяльності у сорері фрінансів, розроблення та затвердження концепцій та програм загальнодержавного значення.

Основи розподілу компетенційних повноважень щодо виконання фрункції фрормування державної фрінансової політики між Президентом України, Верховною Радою України та Кабінетом Міністрів України закріплені в Конституції України. При цьому не наголошено, якому 3 низки державних органів відведена провідна роль у здійсненні даного процесу.

тому сьогодні в Україні недостатньо вирішена проблема створення цілісної системи державного фрінансового контролю. Постає питання невизначеності правового поля діяльності державних контролюючих органів, паралелізм в роботі, дублювання їхніх фрункцій та повноважень, відсутність узгодженої взаємодії та спеціалізації при проведенні перевірок та виконанні покладених повноважень.

Функцію реалізації державної орінансової політики доцільно визначити як діяльність уповноважених державних органів, що спрямована на досягнення тактичних і оперативних цілей, а також на забезпечення вирішення конкретних завдань та застосування відповідних засобів державного впливу на суспільні відносини у фрінансовій сорері [2, с. 117].

Функції формування та реалізації державної фрінансової політики неможливо досліджувати у відриві від фрункції контролю за ії виконанням, який доцільно систематизувати як:

1) контроль 3 боку органів державного нагляду за підконтрольними їм об'єктами щодо виконання ними владних рішень, прийнятих у рамках державної фрінансової політики;

2) нагляд за органами державного управління у фрінансовій сорері щодо виконання ними владних рішень, прийнятих у рамках державної фрінансової політики, усіма уповноваженими на те суб'єктами. Основною метою даного виду контролю є гармонізація діяльності суб'єктів державного управління 3 метою підтримання законності та фрінансової дисципліни в держав- ному секторі. Залежно від того, хто здійснює даний контроль, тобто від суб'єктного складу, розрізняють такі види державного контролю: парламентський, президентський, урядовий, відомчий (міністерський).

Відповідно до інституціонального механізму фрінансова політика являє собою своєрідний економічний інститут, який відповідає за фрормування та реалізацію правил і обмежень щодо економічної поведінки, умов фрінансових відносин, розвитку фрінансової стратегії, регулювання соціально-економічної сорери учасників фрінансових відносин.

Відтак фрінансова політика взаємозалежна із фрінансовими відносинами, що виникають у процесі фрормування та використання ВВП та національного доходу. Тож відповідно до цього вона має бути сорормована з урахуванням науково-обґрунтованої концепції фрінансової системи та визначати подальші механізми та інструменти врегулювання соціально-економічних зрушень задля гармонізації суспільства [3, с. 3].

Задля забезпечення належного рівня фрінансової політики діяльність органів державного нагляду має бути спрямована, перш за все, на забезпечення фрінансової безпеки країни та боротьбу із фрінансової злочинністю. Саме так, органи державного фрінансового нагляду повинні присікти фрінансові порушення і злочини, сприяти розкриттю та запобігають виникненню тіньової економіки шляхом проведення наглядових дій щодо ефективності і законності управління фрінансовими ресурсами держави [4, с. 40].

Про необхідність реформування системи нагляду (контролю) свідчать масштаби тінізації економіки України. Відповідно до оцінок Національного інституту стратегічних досліджень при Президентові України, на сьогодні, рівень тіньової економіки вийшов за межі кінцевого значення (не більше 30\% від ВВП) та перебуває у небезпечній зоні [5]. Дана тенденція свідчить про негативний стан макроекономічної безпеки в державі та зумовлює виведення частини економіки 3 «тіні», що позитивно позначилося б на стабільності фрінансової системи країни. Саме на це і має бути спрямоване вдосконалення інституціональних механізмів забезпечення фрінансової політики та нагляду (контролю).

Під контролем треба розуміти нагляд за підконтрольним об'єктом та дотримання принципів його належного функціонування, відповідно до встановлених норм, шляхом порівняння фрактичного стану із бажаним. 
В теорії контролем $є$ одна із ключових фрункцій управлінської системи, яка включає у себе систему спостереження та перевірки діяльності і фрактичного стану об'єкта. У табл. 1 систематизовано наукові та практичні підходи до визначення сутності понять «контроль» та «фрінансовий контроль».

Відтак, державний нагляд $є$ одним із підвидів фрінансового контролю, який забезпечує процес перевірки господарюючого суб'єкта будь-якої форми власності внаслідок використання відповідних методів та технологій контролю 3 метою виявлення прогалин у фрінансовій діяльності і звітності в процесі створення, розподілу, перерозподілу чи використання фінансових ресурсів.

Як зазначається у МСФЗ, контроль - це своєрідна здатність управляти фрінансовою та господарською політикою задля отримання бажаної вигоди від її діяльності [8, с. 154].

Отож, державний нагляд являє собою фрорму реалізації контролюючої функції фрінансів та кінцевим етапом у процесі державного управління централізованими і децентралізованими фрінансовими ресурсами. У тому випадку, якщо контроль визначає суть фрінансів, то державний фрінансовий нагляд визначає зміст державного управління. Роль та місце нагляду у період активного розвитку ринкових відносин істотно зростає, адже економічні методи управління приходять на зміну адміністративним.

За способами здійснення державний нагляд відбувається у фрормі перевірки, огляду, спостереження, аналізу, оцінки, моні- торингу, інспекції (ревізії), експертизи та аудиту. Завдяки переліченим способам здійснення нагляду, а також їх гармонізації можна досягти максимального ефекту від фрункціонування інституціонального механізму здійснення фрінансової політики держави.

На етапі проведення державного нагляду для покращення ефрективності механізму забезпечення фрінансової політики необхідно дотримуватися принципів законності, економічності, есрективності, результативності та прозорості.

Впродовж останніх років нагляд відіграє важливу роль у використанні державних коштів. Держава використовує бюджет з метою здійснення зовнішнього, внутрішнього та міжгалузевого розподілу і перерозподілу ВВП задля забезпечення державних видатків та соціальних гарантій. У той же час, державний бюджет є есрективним фрінансовим методом організації національної економіки. Саме тому відзначається необхідність у проведенні державного нагляду з метою дотримання законності та доцільності фрінансових операцій, фрормування та використання фрінансових ресурсів цілеспрямовано на соціально-економічний розвиток країни.

Відтак, внаслідок наглядових заходів Рахункової палати України, як суб'єкта парламентського контролю та вищого органу аудиту в державі, було виявлено незаконних бюджетних правопорушень нецільового використання фрінансових фрондів та коштів позабюджетних фондів у 2020 році на суму понад 43 млрд грн [9].

На сьогодні, у світі процес нагляду за фрінансовою політикою $є$ визначенням та під-

Таблиця 1

Підходи до визначення понять «контроль» та «фрінансовий контроль»

\begin{tabular}{|c|c|}
\hline Автор & Визначення \\
\hline М. Головань & $\begin{array}{l}\text { Перевірка виконання певних господарських операцій задля визначення } \\
\text { їх законності та цілеспрямованості. }\end{array}$ \\
\hline Л. Дікань & $\begin{array}{l}\text { Управлінська фрункція чи економічна категорія, що відображає } \\
\text { прикладний аспект та має теоретичне значення. }\end{array}$ \\
\hline $\begin{array}{l}\text { Н. Виговська, } \\
\text { О. Стеблянко }\end{array}$ & $\begin{array}{l}\text { Нагляд за дотриманням визначених норм органами влади всіх рівнів у } \\
\text { процесі діяльності всіх економічних суб'єктів. }\end{array}$ \\
\hline М. Коцупатрий & $\begin{array}{l}\text { Комплексна і цілеспрямована фрінансово-правова діяльність органів } \\
\text { фрінансового контролю або їх підрозділів чи представників, а також осіб, } \\
\text { уповноважених здійснювати контроль, що базується на положеннях } \\
\text { актів чинного законодавства. }\end{array}$ \\
\hline $\begin{array}{c}\text { ЗУ «Про основні } \\
\text { засади державного } \\
\text { нагляду (контролю) у } \\
\text { ссрері господарської } \\
\text { діяльності» }\end{array}$ & $\begin{array}{l}\text { Діяльність уповноважених законом ЦОВВ, їх територіальних органів, } \\
\text { державних колегіальних органів, місцевих державних адміністрацій, } \\
\text { органів місцевого самоврядування в межах повноважень, передбачених } \\
\text { законом, щодо виявлення та запобігання порушенням вимог законодавства } \\
\text { суб'єктами господарювання та забезпечення інтересів суспільства, зокрема } \\
\text { належної якості продукції, робіт та послуг, допустимого рівня небезпеки для } \\
\text { населення, навколишнього природного середовища. }\end{array}$ \\
\hline
\end{tabular}

Джерело: сфрормовано на основі [1, с. 237; 4, с. 40; 6, с. 6; 7] 
твердженням ролі і значення держави у регулюванні розвитку національної економіки та підвищення добробуту населення.

Формування єдиної системи фрінансового нагляду (контролю) неможливе без урахування і чинної законодавчої та нормативноправової бази, і напрацьованих пропозицій щодо [10, с. 286]:

- фрормування та зміцнення незалежного фрінансового нагляду, правових основ його здійснення, структури й організації;

- форомування єдиної системи державного орінансового нагляду відповідно до мети їі створення;

- розмежування повноважень органів державного фрінансового нагляду при проведенні контрольно-ревізійної та експертно-аналітичної діяльності;

- вдосконалення і координації діяльності контролюючих органів у єдиній системі державного орінансового нагляду.

Оскільки фрінансова політика в інституціональній площині представляє комплекс заходів державних інституцій щодо врегулювання фрінансових ресурсів, спрямованих на виконання інституційний фрункцій, то, відповідно, контроль має здійснюватися за оптимальною структурою ссрормованих інституцій та забезпечувати пріоритетні напрями розвитку фрінансової політики. Організаційну структуру єдиної системи фрінансового нагляду (контролю) наведено на рис. 1.

Загалом для фрормування ефективної системи фрінансового нагляду слід враховувати такі складові:

- комплекс органів державного фрінансового нагляду;
- відносини між органами контролю та владою;

- визначення системи підпорядкування органів контролю;

- встановлення об'єктів та підконтрольних суб'єктів нагляду;

- визначення інструментів, форма та методів, які використовуватимуть суб'єкти нагляду;

- визначення прав та обов'язків суб'єктів і підконтрольних об'єктів нагляду.

Функціонування наглядової системи має бути спрямовано на досягнення поставлених цілей орінансової політики України. Призначення системи державного нагляду (контролю) полягає у моніторингу ефеективності використання фрінансових ресурсів, оптимальності фрінансових потоків, створення інформаційної бази для прийняття фрінансових рішень щодо усунення недоліків чи регулювання цілей фрінансової політики.

Подальший розвиток інституціонального механізму здійснення фрінансової політики треба зосередити на основних здобутках науковців протягом останніх років, а особливо у сорері врегулювання та контролю системи державного контролю та врегулювання фрінансової політики задля подальшого соціального-економічного розвитку нації.

Погоджуємось із І. Адаменко, який наголошує, що інституціональний механізм фрінансової політики у фрормі економічного інституту визначає норми та положення, встановлює обмеження щодо поведінки та розвитку взаємовідносин учасників фрінансової політики задля врегулювання та гармонізації соціально-економічної сорери [11, с. 342].

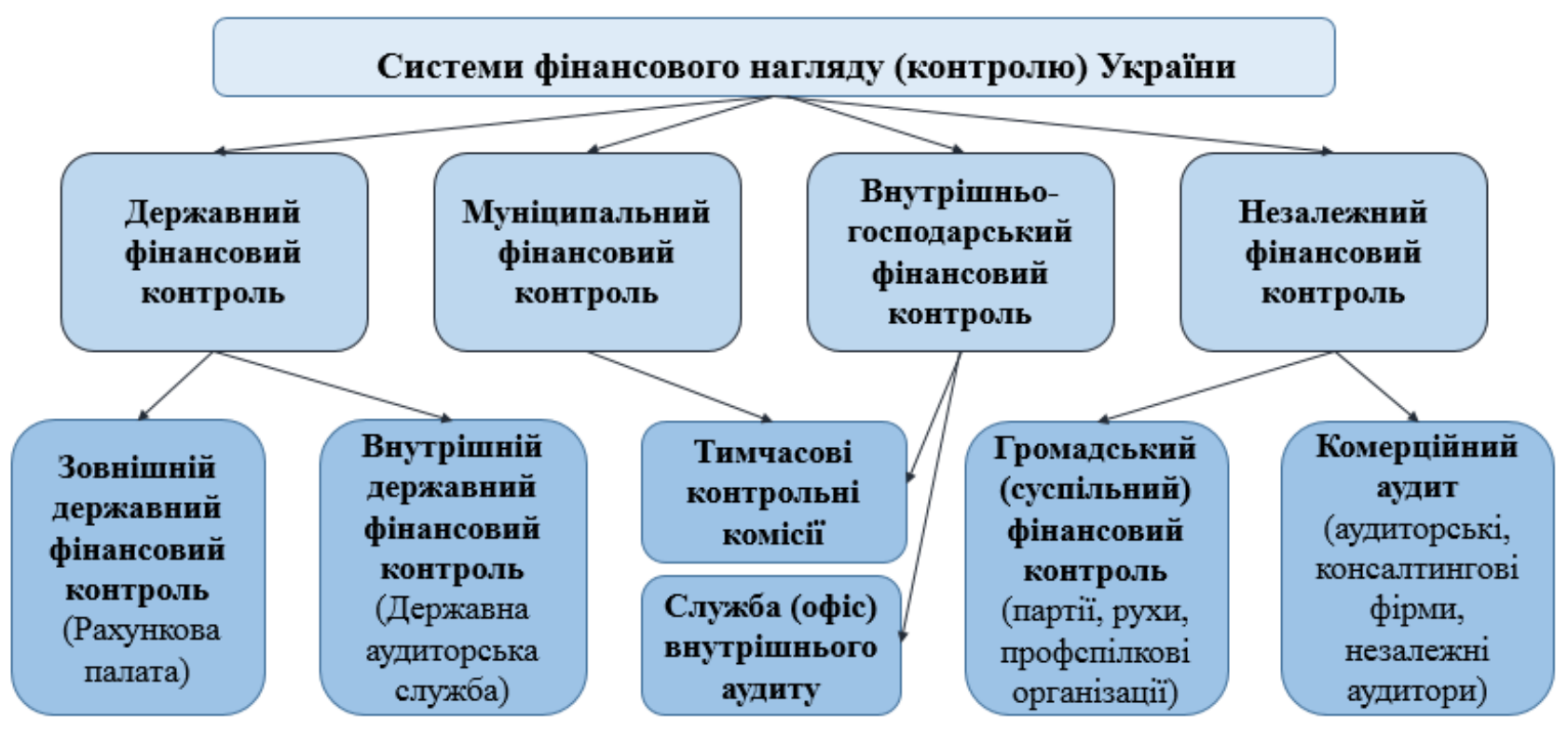

Рис. 1. Системи фрінансового нагляду (контролю) України 
Отже, інституціональний механізм регулювання фрінансової політики визначає етап формування раціональної структури ефективних економічних інститутів, які сприятимуть виконанню наглядових дій на державному та територіальному рівнях, відповідно до визначених реформ.

Наявний інституціональний механізм регулювання державної фрінансової політики потребує певних змін у своїй структурі та змістовного наповнення, відповідно до зовнішньої та внутрішньої політики держави та стандартів міжнародних фрінансових інститутів.

Також треба зауважити, що інституціональні механізми здійснення фрінансової політики фрормуються відповідно до місця та ролі державного нагляду (контролю) у загальних срункціях держави та соціально-економічних процесах. Нині, в умовах активних глобалізаційних процесів фрормування дієвої фрінансової політики у системі інституціонального регулювання має полягати у фрормуванні ефрективного механізму фрінансових відносин, які б сприяли досягненню цілей стратегічного розвитку країни.

Ефрективність нагляду (контролю), перш за все, залежить від типу фрінансової політики, а також іiі стратегічного та тактичного спряму- вання. Адже вони мають взаємодоповнювати та сприяти розвитку. У такому випадку, фрінансовий контроль та політика буде спрямованою на максимальний рівень забезпечення фрінансового регулювання та стабілізації фрінансової політики країни. 3 огляду на вищесказане, основним перспективним напрямом удосконалення інституціонального механізму здійснення фрінансової політики на усіх рівнях $€$ становлення системи фрінансового нагляду внаслідок дотримання нижченаведених на рис. 2 рекомендацій.

Висновки та подальші перспективи дослідження. Підсумовуючи, слід зазначити, що фрінансова політика сьогодення покликана забезпечувати інституційні передумови у фрормуванні та реалізації фрінансової моделі країни, яка побудована на загальноприйнятих нормах та положеннях, організаційно-управлінських структурах, які утворюють комплексний механізм стабілізації соціально-економічного становища та підвищення добробуту нації.

Основними завданнями на сучасному етапі ресрормування системи державного управління $€$ форомування належних умов, що сприятимуть стабільній та ефективній реалізації фрінансової політики в інституціональному середовищі, активізації інвестиційної діяль-

\section{Напрями модернізації інституціональних засад державного фінансового нагляду}

Удосконалення нормативно-правового забезпечення внаслідок формування та реалізації Закону щодо основних положень фінансового нагляду.

Положення даного Закону мають описувати суть, мету, цілі, етапи та методи проведення фінансового нагляду та діяльності наглядових органів

Визначення ролі та вагомості наглядових органів у процесі проведення перевірок, надання звітності та висновків, визначення та дослідження передумов появи прогалин у фінансовій політиці, формування та реалізація заходів щодо усунення даних недоліків

Зниження кількості наглядових органів щодо забезпечення фінансової політики та формування відповідальних органів за визначенням підконтрольного об'єкту

Забезпечення суспільства чіткими та достовірними даними щодо формування та використання фінансових ресурсів на державному та територіальному рівнях щодо залучення державних коштів,

а також зобов'язання наглядових органів на оприлюднення результатів нагляду (контролю) за здійсненням фінансової політики

Рис. 2. Напрями удосконалення інституціонального механізму забезпечення контролю у здійсненні фінансової політики 
ності країни, ефрективного фрункціонування наглядової системи шляхом оптимізації контрольного навантаження, удосконалення та гармонізації системи фрінансового контролю.

Реалізація есрективного державного нагляду у процесі здійснення фрінансової політики відіграє чималу роль у становленні раціональної і цілеспрямованої економічної політики, тим самим забезпечуючи належний рівень фрінансової безпеки держави. Крім того, фрінансовий нагляд має посідати вагоме місце у інституціональному механізмі реалізації орінансової політики, надаючи їй належний рівень фрункціонування фрінансового механізму та встановлення єдиних норм формування фрінансових взаємовідносин, захисту економічних інтересів держави та дотримання фрінансової дисципліни, що сприятиме раціональності та ефрективності фрінансової політики.
Пристосування фрінансової політики до сучасних умов чимало пов'язана зі зміною інституційного середовища суспільства, тому будь-які зміни у фрінансовій політиці держави мають враховувати стан інституційного середовища. Фінансова політика як динамічна система, що розвивається залежно від соціально-економічних потреб суспільства 3 метою активного впливу на економіку, має задіяти, перш за все, інституціональні механізми фрінансового контролю. Структурні зміни та необхідність виходу на якісний рівень економічного зростання та розвитку концентрують увагу на способах удосконалення інституціонального механізму забезпечення срінансової політики та фрінансового нагляду, який має бути сорормовано відповідно до потреб економіки та суспільства, проблем і перспектив розвитку нації.

\section{СПИСОК ВИКОРИСТАНИХ ДЖЕРЕЛ:}

1. Виговська Н.Г., Дячек С.М. Транссрормація державного фрінансового контролю в контексті забезпечення національної економічної безпеки. Приазовський економічний вісник. 2019. № 5(16). С. 234-238.

2. Кміть В., Мельничук М. Інституціональний механізм здійснення державної податкової політики в Україні / Збірник наукових праць молодих вчених Тернопільського національного економічного університету «Наука молода». Випуск 6. Тернопіль : Економічна думка, 2006. С. 114-119.

3. Васільєва Л.М., Дацій Н.В., Залізнюк В.П. Ефективність фрінансового контролю в системі державного управління. Державне управління: удосконалення та розвиток. 2020. № 3. С. 1-5.

4. Ботвіна Н. Фінансовий контроль за функціонуванням системи та механізму фінансової політики держави. Економічний аналіз. 2020. Том 30. № 1. Частина 1. С. 38-41.

5. Національний інститут стратегічних досліджень : офіційний веб-сайт. URL: https://niss.gov.ua/ doslidzhennya/ekonomika (дата звернення: 16.10.2021).

6. Гуцаленко Л.В., Дерій В.А., Коцупатрий М.М. Державний фрінансовий контроль : навч. посіб. Київ : Центр учбової літератури, 2009. 424 с.

7. Про основні засади державного нагляду (контролю) у сфері господарської діяльності : Закон України від 5 квітня 2007 р. № 877-V / Верховна Рада України. URL: https://zakon.rada.gov.ua/laws/show/877-16\#Техt (дата звернення: 21.20.2021).

8. Моісеєнко О.М. Формування інституціонального механізму державного управління економічним розвитком України : дис. канд. наук з держ. управління : 25.00.02. Чернігів, 2021. 248 с.

9. Висновок про результати аналізу виконання закону про Державний бюджет України на 2020 рік / Рахункова палата України. URL: https://rp.gov.ua/upload-files/Activity/Collegium/2020/31-2_2020/Vysn_31 2_2020.pdf (дата звернення: 17.10.2021).

10. Загорський В.С., Піхоцький В.Ф. Державний фрінансовий контроль у системі державного управління. Ерективність державного управління. 2015. Вип. 42. С. 283-289.

11. Адаменко І.П. Фінансова політика як інструмент соціально-економічного розвитку країни. Бізнес Інфрорм. 2014. № 3. С. 341-345.

\section{REFERENCES:}

1. Vygovska N.H., Diachek S.M. (2019) Transformatsiya derzhavnogo finansovogo kontroliu v konteksti zabezpechennia natsionalnoyi ekonomichnoyi bezpeky [Transformation of state financial control in the context of ensuring national economic security]. Priazovsky Economic Bulletin, vol. 16, no. 5, pp. 234-238.

2. Kmit V., Melnychuk M. (2006) Instytucionalnyy mexanizm zdijsnennia derzhavnoyi podatkovoyi polityky v Ukraini [Institutional mechanism of state tax policy implementation in Ukraine]. Proceedings of the Nauka moloda (Ukraine, Ternopil, 2006), Ternopil: Economic thought, pp. 114-119. 
3. Vasilieva L.M., Datsiy N.V., Zalizniuk V.P. (2020) Efektyvnist finansovogo kontrolyu v systemi derzhavnogo upravlinnia [Effectiveness of financial control in the system of public administration]. Public administration: improvement and development, no. 3, pp. 1-5.

4. Botvina N. (2020) Finansovyy kontrol za funktsionuvanniam systemy ta mekhanizmu finansovoyi polityky derzhavy [Financial control over the functioning of the system and mechanism of financial policy of the state]. Economic analysis, t. 30, no. 1, part 1, pp. 38-41.

5. National Institute for Strategic Studies. Available at: https://niss.gov.ua/doslidzhennya/ekonomika (accessed 16 October 2021).

6. Hutsalenko L.V., Deriy V.A., Kotsupatryy M.M. (2009) Derzhavnyy finansovyy control [State financial control]. Kyiv: Center for Educational Literature. (in Ukrainian)

7. Verkhovna Rada of Ukraine (5 April 2007) Zakon Ukrayiny pro osnovni zasady derzhavnogo nahlyadu (kontrolyu) u sferi hospodarskoyi diialnosti [The law of Ukraine on the basic principles of state supervision (control) in the sphere of economic activity]. Available at: https://zakon.rada.gov.ua/laws/show/877-16\#Text (accessed 21 October 2021).

8. Moiseienko O.M. (2021) Formuvannia instytutsionalnogo mekhanizmu derzhavnogo upravlinnia ekonomichnym rozvytkom Ukrainy [Formation of the institutional mechanism of state management of economic development of Ukraine] (PhD Thesis), Chernihiv: Chernihiv Polytechnic National University.

9. Accounting Chamber of Ukraine (2021) Vysnovok pro rezultaty analizu vykonannia zakonu pro Derzhavnyi byudzhet Ukrayiny na 2020 rik [Conclusion on the results of the analysis of the implementation of the law on the State Budget of Ukraine for 2020]. Available at: https://rp.gov.ua/upload-files/Activity/Collegium/2020/31-2_2020/ Vysn_31-2_2020.pdf (accessed 17 October 2021).

10. Zahorskyy V.S., Pikhotskyy V F. (2015) Derzhavnyy finansovyy kontrol u systemi derzhavnogo upravlinnia [State financial control in the system of public administration]. Efficiency of public administration, vol. 42, pp. 283-289.

11. Adamenko I.P. (2014) Finansova polityka yak instrument sotsialno-ekonomichnogo rozvytku krainy [Financial policy as an instrument of socio-economic development of the country]. Business Inform, no. 3, pp. 341-345. 